\title{
Effect of Bioresources on Fusarium Basal Rot and Purple Blotch Diseases of Garlic (Allium sativum)
}

\author{
Vineeth Masireddy* and Sobita Simon \\ Department of Plant Pathology, Sam Higginbottom University of Agriculture, Technology and \\ Sciences, Prayagraj-211007, Uttar Pradesh, India \\ *Corresponding author
}

\section{A B S T R A C T}

\section{Keywords}

Basal rot, botanicals, compost,garlic,micr oalgae, purple blotch

\section{Article Info}

Accepted: 22 April 2021

Available Online: 10 May 2021
Garlic (Allium sativum) is one of the important bulb crops grown and used as a spice or condiment throughout India. Mostly garlic diseases are either soil- or seed-borne diseases. Among the garlic diseases fusarium basal rot and purple blotch diseases are most destructive diseases, and causes considerable loss in the yield and quality of the produce. An experiment was conducted in-vitro to evaluate the efficacy of five botanical extracts on the radial mycelial growth of Fusarium oxysporum f. sp. cepae, at three concentrations i.e., 5\%, $10 \%$ and $15 \%$, all the five botanicals exhibited significant mycelial growth inhibition of $F$. oxysporum f. sp. cepae, among five botanicals tested, significantly highest average mycelial growth inhibition was recorded with Ageratum conyzoides ( $89.5 \%$ ) followed by Bryophyllum pinnatum (86.9\%). A field experiment was conducted on selected bioresources which were treated on Fusarium basal rot and purple blotch diseases of garlic. Among all the treatments significantly reduced disease incidence of Fusarium oxysprum f.sp cepae (18\%) and disease intensity of Alternaria porri (20.47\%) were found in $\mathrm{T}_{6}$ (Microalgae+VC+SMC) followed by $\mathrm{T}_{3}$ (Microalgae). Similarly, among treatments $\mathrm{T} 6$ (Microalgae+VC+SMC) exhibited significantly highest average yield (132.58q/ha), plant height $(74.6 \mathrm{~cm})$, number of cloves (21), bulb weight $(30.0 \mathrm{~g})$, bulb diameter $(5.61 \mathrm{~cm})$.

\section{Introduction}

Garlic (Allium sativum) is one of the important bulb crops grown and used as a spice or condiment throughout India. Among the garlic diseases incidence of fungus like Alternaria porri, Fusarium spp., cause diseases purple blotch, basal rot and respectively (Ghangaonkar, 2013). Majorly Fusarium basal rot causes severe damage on the field and also in storage Fusarium causes $45 \%$ less yield than normal. main symptoms are Fusarium basal rot is a disease which attacks the basal plate region and the roots.

Warm soil temperatures and high soil moisture promote disease development (Fuentus et al., 2013). Fusarium oxysporum has wide host 
range crops like onion, cabbage, carrot etc., (Takakuwa et al.,1977). Purple blotch causes $20-60 \%$ losses in the field and the main symptoms are appears on leaves as small whitish sunken lesions with purple centers that rapidly enlarge. The leaves fall over gradually (Prajapati et al., 2018). Alternaria porri has wide host range crops like onion, safflower, sunflower, brinjal etc., (Sharma and Ratnoo, 2018).

Composts have shown suppressive effect on several diseases in the field (Noble, 2005). Microalgae act as bio fertilizer and bio stimulant that stimulate the plant growth promoting hormones and generating multiple benefits, such as enhanced rooting, higher crop yields and suppress diseases (Domenico et al., 2019). Vermicompost is the efficient organic manures, it is helpful to improve the soil health and plant health (Lazcanoa and Dominguez, 2011). Spent mushroom compost use found effective against bacterial disease like bacterial wilt of tomato etc., (Zeeshan et al., 2016). SMS reduced intensity of basal rot disease in shallot (Yusidah and Istifadah, 2018).

Botanicals has been advocated as one of promising alternatives trategy to overcome the problems of diseases for the alternation of chemicals. Use of plant extracts is considered as cost effective and eco-friendly approach of disease management, without any environmental pollution (Kumarandkumar, 2015).

In recent years, there has been a major thrust on pesticide residue free organic food production. Taking the task into consideration, efficient bioresources and botanicals need to be explored to fit into the management schedule. Use of bioresources and botanicals for the management of various diseases of crop plants is eco-friendly and environmentally safe.

\section{Materials and Methods}

\section{Isolation and identification of Fusarium oxysporum f. sp. cepae}

Infected leaves of garlic were washed first in water and then in mercuric chloride $\left(\mathrm{HgCl}_{2}\right)$ to disinfect the surface of leaves. After that, leaves were cut into small pieces and transferred to the Petri plates containing PDA (four pieces per plate) and plates were incubated at $25 \pm 2^{0} \mathrm{C}$ for 3-4 days in inverted position. The pathogen (F.oxysporum) isolated in PDA was produced white mycelial growth at first but later it will turn to pinkish color. Aerial mycelium is white cottony to slightly pink in colour, Microconidia were observed, their size was 5-12 $\mu \mathrm{m}$ in length without septation and their shape was oval to kidney shaped. Macroconidia were also observed. Their size ranged from 4 to $7 \mu \mathrm{m}$ wide and 20$35 \mu \mathrm{m}$ long. Number of septa were usually four to five, gradually attenuate toward apex, falcate shaped. Chlamydospores usually abundant, composed of one or two round cells and have thick cell wall and were formed in or on oldermycelium (Booth, 1975).

\section{Isolation and identification of Alternaria porri}

The infected leaves were brought and cut into small pieces surface sterilized. Sterilized pieces were placed on Potato Dextrose Agar (PDA) medium in petri plates under aseptic conditions and incubated $25 \pm 2^{\circ} \mathrm{C}$ for 3-4 days in inverted position. The pathogen (Alternaria porri) isolated in PDA was produced black mycelial growth. Conidiophores arising singly or in small groups, pale to mid brown, Conidia single, straight or slightly curved, obclavate or with body of conidium ellipsoidal and tapering to a beak, overalllength $100-300 \mu \mathrm{m}, \quad 15-$ 20 $\mu$ mwide,pale,smooth,8-12 transversesepta, 0-7 longitudinal orobliquesepta (Gupta et al., (2014)). 
In-vitro efficacy of botanical extracts against Fusraium oxysporum f. sp. cepae

Leaves were collected and washed thoroughly in tap water followed by sterilized distilled water, air dried and grinded with mortar and pestle with the addition of distilled water at the ratio of 1:1 (w/v). The extract obtained was filtered through double layered muslin cloth. After autoclaving PDA media and cooling it to $50^{\circ} \mathrm{C}$. required amount of this standard solution was mixed into PDA to get final concentration of 5\%,10\% and $15 \%$ for poisoned food technique.

Twenty $\mathrm{ml}$ of amended PDA was poured in each $90 \mathrm{~mm}$ sterilized Petriplate and allowed to solidify. Control treatment was maintained without adding plant extracts on PDA. A circular disc of $7 \mathrm{~mm}$ diameter from 9 days old culture of Fusraium oxysporum f. sp. cepae was cut with sterilized cork borer and inoculated in the center of solidified amended as well as control media. Each treatment was replicated in three Petri plates. Then the Petriplates were incubated at $27 \pm 1^{\circ} \mathrm{C}$, and the inhibitory effect of botanical extracts against radial mycelial growth of Fusraium oxysporum f. sp. cepae was recorded at every $24 \mathrm{hrs}$ interval. The mycelial growth and percent inhibition was calculated using the formula (Vincent, 1947).

Percent Inhibition(I)

(C-T)

$=------\times 100$

$\mathrm{C}$

where,

$\mathrm{I}=$ Percent inhibition (\%).

$\mathrm{C}=$ Growth of the test fungus in untreated control plate

$\mathrm{T}=$ Growth of the test fungus in treated control plates.

\section{Evaluation of bioresources on field}

A field experiment was carried out in Central Research Field, SHUATS, Naini, Prayagraj during Rabi 2019-20. The experiment was laid out in Randomized block design. With three replications and six treatments. The bioresources such as spent mushroom compost, vermicompost, microalgae and microalgae combinations with vermicompost and spent mushroom compost were evaluated against Fusarium basal rot and purple blotch diseases of garlic. Vermicompost and spent mushroom compost were applied before sowing, and microalgae mixed in water and was applied to the rhizosphere area after one week of germination. Followed by two more sprays, 60, 90 DAS and observations(plant height $(\mathrm{cm})$, no. of cloves, bulb weight $(\mathrm{g})$, bulb diameter $(\mathrm{cm})$, Yield $(\mathrm{q} / \mathrm{ha}))$ were recorded and disease incidence and disease intensity or percent disease incidence were calculated by using following formula

Disease incidence $(\%)$

No. of plants showing disease symptoms

= -

Total no of plants observed

Disease intensity was calculated by applying 0 -5 grade disease rating scale (Table 1)

\section{Percent Disease Incidence (PDI)}

Based on numerical rating observed, Percent Disease Incidence (PDI) was worked out applying the formula given by Mc Kinney (1923).

Percent disease index

Sum of all individual

disease rating

$=$--- $\times 100$

Total No. of plant assessed

$\times$ Maximum rating 


\section{Results and Discussion}

In-vitro efficacy of botanical extracts against radial mycelial growth of Fusraium oxysporum f sp. cepae

The results revealed in table (4) and figure no (1) revealed that all the botanicals tested were significantly effective in inhibiting the growth of pathogen over control. The results indicated that increase in percent inhibition was variably in proportion to increase in the concentration $(5 \%, 10 \%, 15 \%)$ of the plant extracts.

Average radial mycelial growth of the test pathogen was ranged from $17.67 \mathrm{~mm}$ (Ageratum conyzoides) to $47.13 \mathrm{~mm}$ (Mentha spicata). However, it was significantly least with Ageratum conyzoides (17.67mm) followed by Bryophyllum pinnatum (20.93mm), Sida acuta (29.55mm), Trigonella foenum graecum (42.5mm), Mentha spicata(47.13).

Results revealed that all the five botanicals tested exhibited a wide range of mycelial growth inhibition of F.oxysporum and it was decreased drastically with increase in concentrations of the test botanicals from 10 to $15 \%$.Average mycelial growth inhibition of the test pathogen was ranged from 80.35(Ageratum conyzoides) to 46.49 (Mentha spicata).

However, it was significantly least with Ageratum conyzoides ( $80.35 \%$ ) followed by Bryophyllum pinnatum (76.71\%), Sida acuta (67.15\%), Trigonella foenum graecum (52.66\%), Mentha spicata (46.49\%).
Efficacy of bioresources on Fusarium basal rot and purple blotch diseases of garlic

\section{Efficacy of bioresources on Fusarium basal rot of garlic}

Results revealed that all the treatments were significantly reduced the disease incidence of Fusarium oxysporum f.sp cepae in garlic when compared to control. Disease incidence of $F$. oxysporum f. sp cepae lowest in Microalgae + VC+SMC (18.00\%) followed by Microalgae (20.33\%), Vermicompost (34.6\%), Microalgae +VC (38.3\%), Microalgae +SMC (41.6\%), spent mushroom Compost (44.0\%) and control (68\%) (Table 5). However, among the treatments $\left(\mathrm{T}_{2}\right.$ and $\left.\mathrm{T}_{3}\right)$ were found nonsignificant whereas $\left(\mathrm{T}_{1}, \mathrm{~T}_{5}\right)(\mathrm{T} 5, \mathrm{~T} 4)(\mathrm{T} 4, \mathrm{~T} 2)$ (T3, T6) are found significant over control.

\section{Efficacy of bioresources onpurple blotch disease of garlic}

Results revealed that all the treatments were significantly reduced the disease intensity of Alternaria porriin garlic at 120 DAS when compared to control.

Disease intensity of Alternaria porri lowest in Microalgae $+\mathrm{VC}+\mathrm{SMC}(20.4 \%)$ followed by Microalgae (27.33\%), Vermicompost (33.1\%), Microalgae + VC (44.7\%), Microalgae +SMC (51.1\%), spent mushroom Compost $(52.6 \%)$ and control(63.58\%)(Table.6). However, among the treatments (T1,T5) were found non-significant, whereas (T3,T2) (T2,T4) (T4,T5)are found significant over control. 
Table.1 Botanicals/Phyto extracts used

\begin{tabular}{|c|c|c|c|}
\hline Tr. No & Scientific name & Plant part used & Conc. used (\%) \\
\hline $\mathbf{T}_{\mathbf{1}}$ & Trigonella foenum-graecum & Leaf & $5 \%, 10 \%, 15 \%$ \\
\hline $\mathbf{T}_{\mathbf{2}}$ & Mentha spicata & Leaf & $5 \%, 10 \%, 15 \%$ \\
\hline $\mathbf{T}_{\mathbf{3}}$ & Bryophyllumpinnatum & Leaf & $5 \%, 10 \%, 15 \%$ \\
\hline $\mathbf{T}_{\mathbf{4}}$ & Ageratum conyzoides & Leaf & $5 \%, 10 \%, 15 \%$ \\
\hline $\mathbf{T}_{\mathbf{5}}$ & Sida acuta & Leaf & $5 \%, 10 \%, 15 \%$ \\
\hline $\mathbf{T}_{\mathbf{0}}$ & Control & & \\
\hline
\end{tabular}

Table.2 List of bioresources used in field

\begin{tabular}{|c|c|c|}
\hline S.no & Treatment no. & Treatment name \\
\hline 1 & T0 & Control \\
\hline 2 & $\mathbf{T}_{1}$ & Spent Mushroom Compost@ 10t/ha \\
\hline 3 & $\mathbf{T}_{2}$ & Vermicompost@8t/ha \\
\hline 4 & $\mathbf{T}_{3}$ & Microalgae@4kg/acre \\
\hline 5 & $\mathbf{T}_{4}$ & Microalgae@4kg/acre + vermicompost@8t/ha \\
\hline 6 & $\mathbf{T}_{5}$ & Microalgae@4kg/acre+spentMushroomCompost@10t/ ha \\
\hline 7 & $\mathbf{T}_{6}$ & $\begin{array}{c}\text { Microalgae@4kg/ha + spent mushroom Compost@ 10t/ha + } \\
\text { Vermicompost @8t/ha }\end{array}$ \\
\hline
\end{tabular}

Table.3 Disease rating

\begin{tabular}{|c|c|}
\hline Score/Grade & Description \\
\hline 0 & No disease \\
\hline 1 & $<5 \%$ leaf area affected \\
\hline 2 & $\mathbf{6 - 1 0 \%}$ leaf area affected \\
\hline 3 & $\mathbf{1 1 - 2 5 \%}$ leaf area affected \\
\hline 4 & $\mathbf{2 6 - 5 0 \%}$ leaf area affected \\
\hline 5 & $\mathbf{5 0 \%}$ leaf area affected \\
\hline
\end{tabular}

Table.4 In-vitro efficacy of botanical extracts againstFusraiumoxysporumf sp.cepae

\begin{tabular}{|c|c|c|c|c|c|}
\hline Treatment name & $\begin{array}{c}\text { Radial } \\
\text { mycelial } \\
\text { growth } \\
5 \%(\mathrm{~mm}) *\end{array}$ & $\begin{array}{c}\text { Radial } \\
\text { mycelial } \\
\text { growth } \\
10 \%(\mathbf{m m})^{*}\end{array}$ & $\begin{array}{c}\text { Radial } \\
\text { mycelial } \\
\text { growth } \\
15 \%(\mathbf{m m})^{*}\end{array}$ & $\begin{array}{l}\text { Average radial } \\
\text { mycelial } \\
\text { growth }(\mathbf{m m})\end{array}$ & $\begin{array}{c}\text { Inhibition } \\
\% \\
\text { (mean of } \\
\text { three conc.) }\end{array}$ \\
\hline $\begin{array}{c}\text { Trigonella } \\
\text { foenumgraecum }\left(\mathrm{T}_{1}\right)\end{array}$ & 53.5 & 46.43 & 27.83 & 42.58 & 52.66 \\
\hline Mentha spicata $\left(\mathbf{T}_{2}\right)$ & 60.93 & 45.53 & 37.93 & 47.13 & 46.49 \\
\hline $\begin{array}{l}\text { Bryophyllum } \\
\text { pinnatum }\left(\mathrm{T}_{3}\right)\end{array}$ & 31.0 & 20.10 & 11.73 & 20.95 & 76.71 \\
\hline $\begin{array}{c}\text { Ageratum } \\
\text { conyzoides }\left(\mathrm{T}_{4}\right)\end{array}$ & 27.3 & 16.3 & 9.43 & 17.67 & 80.35 \\
\hline Sida acuta $\left(\mathbf{T}_{5}\right)$ & 32.6 & 30.0 & 26.06 & 29.55 & 67.15 \\
\hline Control $\left(\mathbf{T}_{0}\right)$ & 90.0 & 90.0 & 90.0 & 90.0 & 0.000 \\
\hline $\mathrm{SE}(\mathrm{d}) \pm$ & 0.635 & 0.722 & 0.671 & & \\
\hline C.D. (at 5\%) & 1.398 & 1.590 & 1.479 & & \\
\hline
\end{tabular}

*mean of three replications 
Table.5 Efficacy of bioresources on Fusarium basal rot of garlic

\begin{tabular}{|c|c|c|c|c|}
\hline \multirow[t]{2}{*}{ Treatments } & \multicolumn{4}{|c|}{ Disease incidence (\%) of fusarium oxysporumf.spcepae } \\
\hline & 30DAS & 60DAS & 90DAS & 120DAS \\
\hline $\mathbf{T}_{\mathbf{0}}-$ Control & 13.33 & 31.30 & 51.66 & 68.00 \\
\hline $\begin{array}{c}T_{1} \text { spent mushroom } \\
\text { Compost(SMC) }\end{array}$ & 11.93 & 30.23 & 39.81 & 44.00 \\
\hline$T_{2}-\operatorname{Vermicompost}(\mathrm{VC})$ & 9.27 & 18.93 & 28.60 & 34.66 \\
\hline $\mathbf{T}_{3}-$ Microalgae(MA) & 6.07 & 13.00 & 17.57 & 20.33 \\
\hline $\mathbf{T}_{4}-$ Microalgae $+\mathrm{VC}$ & 9.75 & 22.40 & 30.70 & 38.33 \\
\hline $\mathrm{T}_{5}-$ Microalgae $+\mathrm{SMC}$ & 10.83 & 28.40 & 37.23 & 41.66 \\
\hline $\mathrm{T}_{6}-\mathrm{Microalgae}+\mathrm{VC}+\mathrm{SMC}$ & 5.40 & 10.40 & 15.87 & 18.00 \\
\hline $\mathrm{SE}(\mathrm{d}) \pm$ & 0.63 & 0.65 & 0.46 & 2.65 \\
\hline C.D. (at 5\%) & 1.32 & 1.35 & 0.96 & 4.58 \\
\hline
\end{tabular}

Table.6 Efficacy of bioresources on purple blotch of garlic

\begin{tabular}{|c|c|c|c|c|}
\hline Treatments & \multicolumn{4}{|c|}{ Disease intensity (\%) of Alternaria porri } \\
\hline & 30DAS & 60DAS & 90DAS & 120DAS \\
\hline T $_{\mathbf{0}}$ - Control & 30.70 & 38.63 & 49.12 & 63.587 \\
\hline $\mathbf{T}_{\mathbf{1}}$ Spent mushroom compost(SMC) & 25.80 & 34.30 & 39.97 & 52.69 \\
\hline $\mathbf{T}_{\mathbf{2}}-$ Vermicompost (VC) & 17.00 & 20.20 & 26.77 & 33.15 \\
\hline $\mathbf{T}_{\mathbf{3}}-$ Microalgae (MA) & 12.87 & 18.30 & 22.47 & 27.367 \\
\hline $\mathbf{T}_{\mathbf{4}}-$ Microalgae +VC & 21.47 & 28.33 & 38.50 & 44.763 \\
\hline $\mathbf{T}_{\mathbf{5}}-$ Microalgae +SMC & 21.97 & 33.70 & 41.43 & 51.18 \\
\hline $\mathbf{T}_{\mathbf{6}}-\mathbf{M i c r o a l g a e}+\mathbf{V C}+\mathbf{S M C}_{\text {SE(d) } \mathbf{+}}$ & 7.00 & 11.17 & 17.12 & 20.473 \\
\hline C.D. (at 5\%) & 1.18 & 0.97 & 0.89 & 1.215 \\
\hline & 2.14 & 2.03 & 1.85 & 2.676 \\
\hline
\end{tabular}

Table.7 Effect of bioresources on plant growth and yield parameters of garlic

\begin{tabular}{|c|c|c|c|c|c|}
\hline Treatments & $\begin{array}{c}\text { Plant } \\
\text { height@ } \\
\text { 120DAS }\end{array}$ & $\begin{array}{l}\text { Number of } \\
\text { cloves }\end{array}$ & $\begin{array}{c}\text { Bulb } \\
\text { weight }(g)\end{array}$ & $\begin{array}{c}\text { Bulb } \\
\text { diameter } \\
(\mathrm{cm})\end{array}$ & $\begin{array}{l}\text { Yield(q/ } \\
\text { ha) }\end{array}$ \\
\hline $\mathbf{T}_{0}-$ Control & 40.3 & 8.0 & 5.3 & 3.5 & 43.47 \\
\hline $\begin{array}{c}\text { T }_{1} \text { spent mushroom compost } \\
\text { (SMC) }\end{array}$ & 52.3 & 13.0 & 12.3 & 4.0 & 72.91 \\
\hline$T_{2}-$ Vermicompost $(\mathrm{VC})$ & 61.0 & 18.3 & 24.6 & 4.7 & 112.05 \\
\hline $\mathbf{T}_{3}-$ Microalgae(MA) & 69.6 & 19.6 & 28.0 & 5.0 & 120.21 \\
\hline $\mathrm{T}_{4}-\mathrm{MA}+\mathrm{VC}$ & 58.5 & 16.6 & 21.0 & 4.3 & 100.94 \\
\hline $\mathrm{T}_{5}-\mathrm{MA}+\mathrm{SMC}$ & 55.0 & 15.6 & 16.3 & 4.2 & 85.72 \\
\hline $\mathrm{T}_{6}-\mathrm{Microalgae}+\mathrm{VC}+\mathrm{SMC}$ & 74.6 & 21.0 & 30.0 & 5.6 & 132.58 \\
\hline $\mathrm{SE}(d) \pm$ & 1.80 & 0.5 & 1.1 & 0.07 & 1.86 \\
\hline C.D. (at 5\%) & 3.9 & 1.24 & 2.51 & 0.17 & 4.09 \\
\hline
\end{tabular}


Fig.1 In-vitro efficacy of botanical extracts against radial mycelial growth of F.oxysporumf sp. Cepae

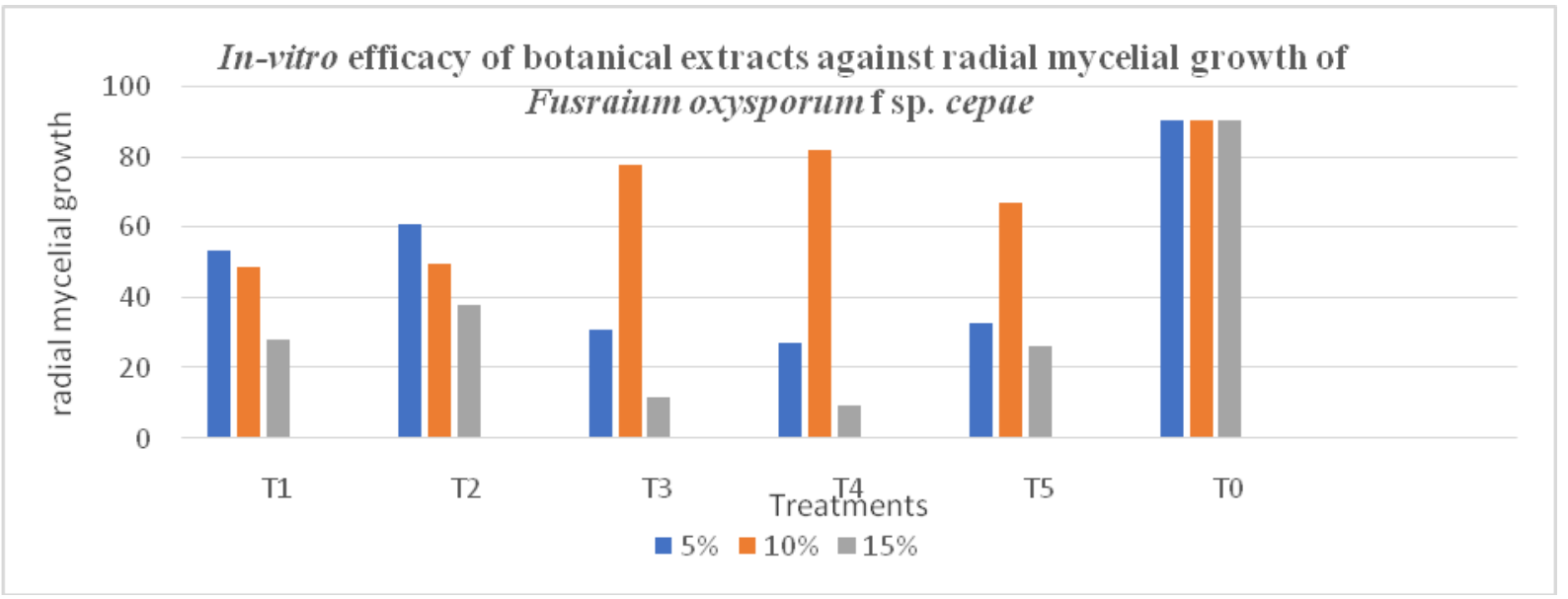

Fig.2 Efficacy of bioresources on Fusarium basal rot

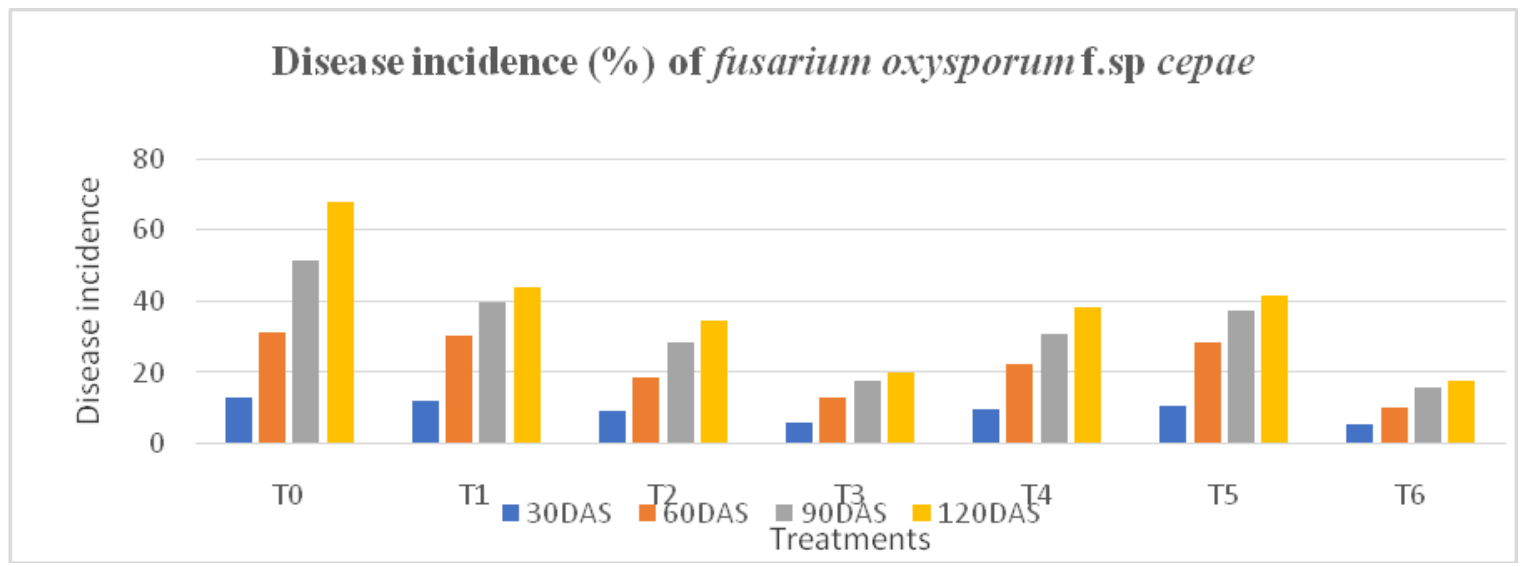

Fig.3 Efficacy of bioresources on purple blotch diseases of garlic

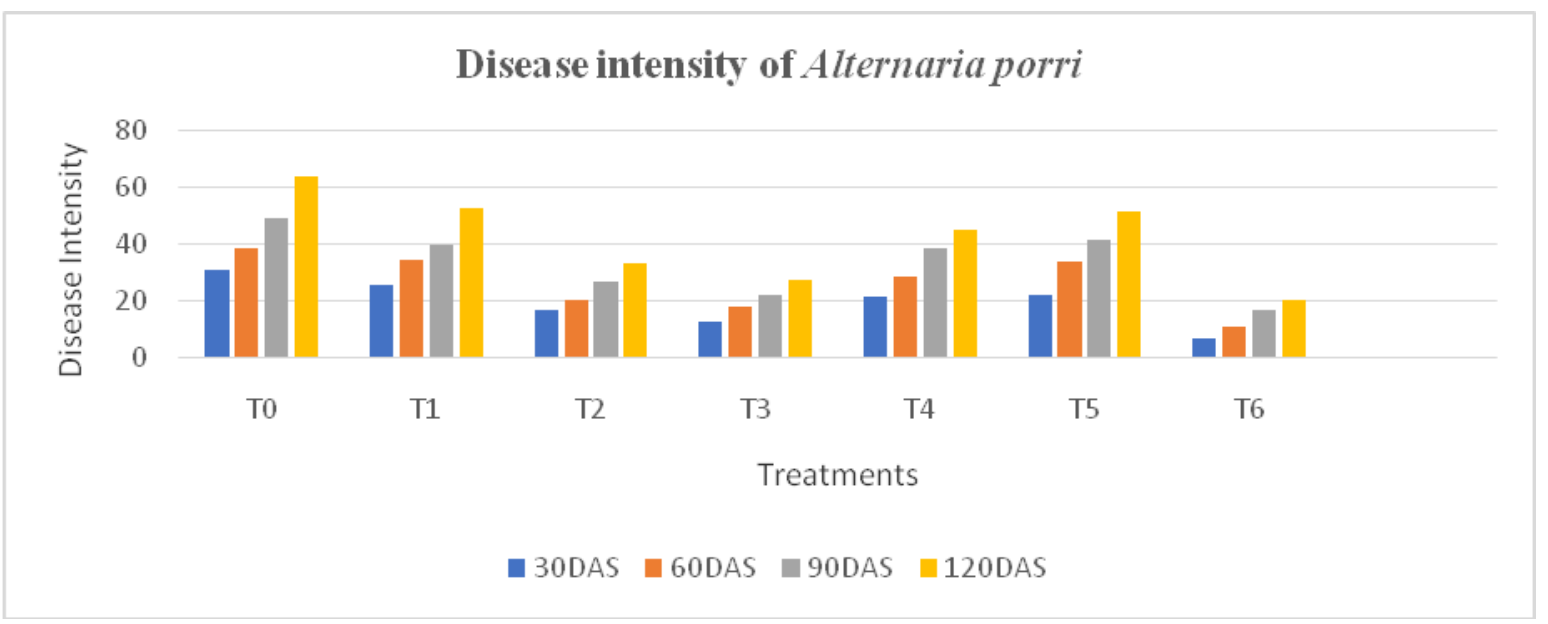


Plate.1 Culture plates of Fusarium oxysporum

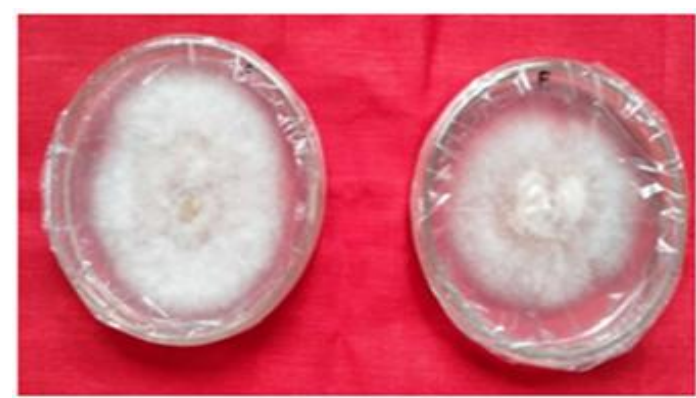

Plate.3 Culture plate of Alternaria porri

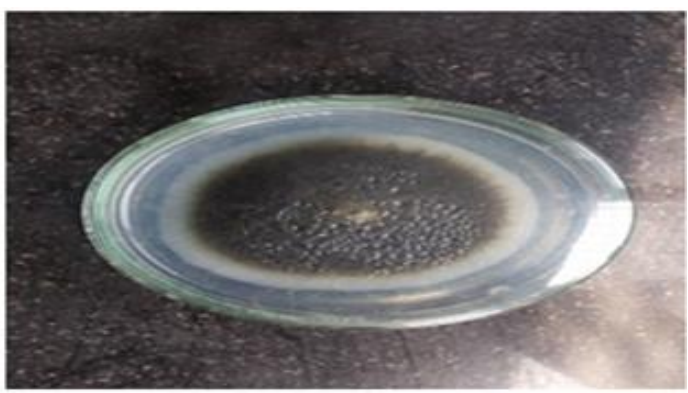

Plate.5 Symptoms of Purple blotch

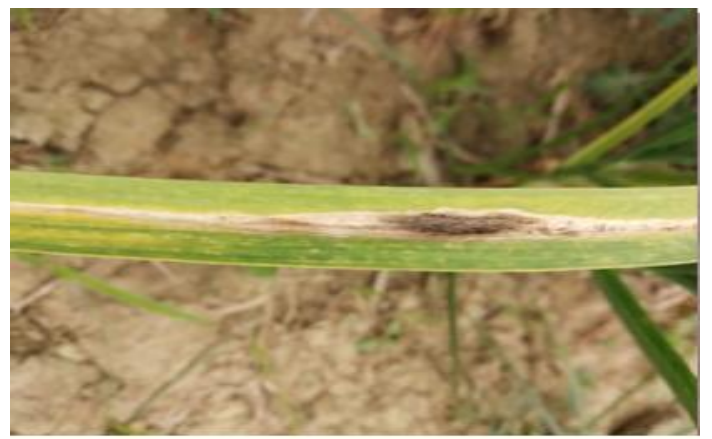

Effect of bioresources on plant growth and yield parameters of garlic

Plant height significantly increased from untreated control $\mathrm{T}_{0}(40.33 \mathrm{~cm})$. Maximum plant height was observed in treatment $\mathrm{T}_{6}$ $(74.66 \mathrm{~cm})$ followed by $\mathrm{T}_{3}(-69.33 \mathrm{~cm}), \mathrm{T}_{2}$ $(61.00 \mathrm{~cm}), \mathrm{T}_{4}(-58.5 \mathrm{~cm}), \mathrm{T}_{5}(55.00 \mathrm{~cm})$ and $\mathrm{T}_{1}$ $(52.33 \mathrm{~cm})$. However, among the treatments $\left(\mathrm{T}_{5}, \mathrm{~T}_{1}\right)\left(\mathrm{T}_{5}, \mathrm{~T}_{4}\right)\left(\mathrm{T}_{2}, \mathrm{~T}_{4}\right)$ are not significantly differ from each other, whereas $\left(\mathrm{T}_{3}, \mathrm{~T}_{2}\right)\left(\mathrm{T}_{3}, \mathrm{~T}_{6}\right)$ found significant over control.

\section{Plate.2 Microscopic view of F.oxysporum}

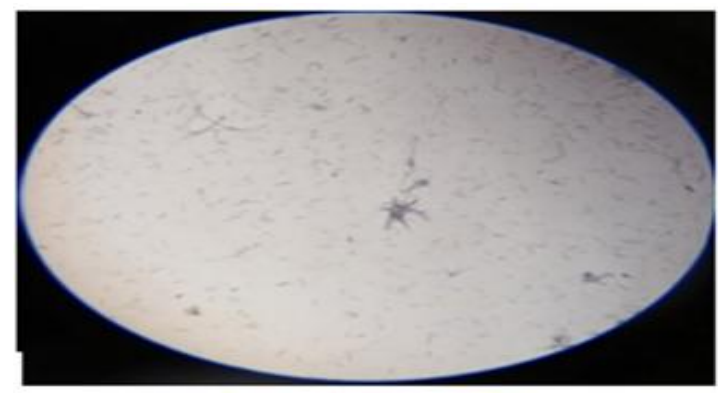

Plate.4 Microscopic view of A.porri

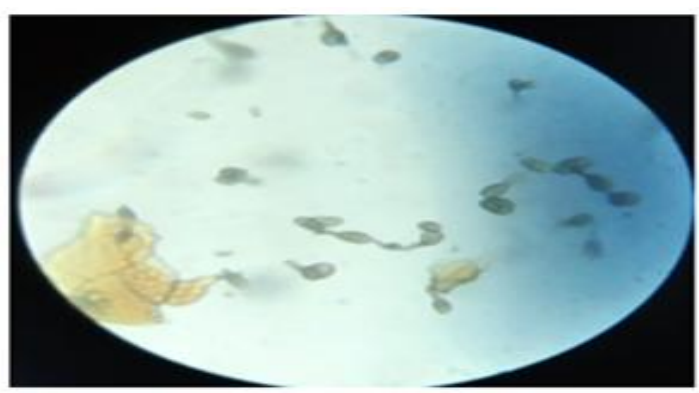

Plate.6 Symptoms of Fusarium basal rot

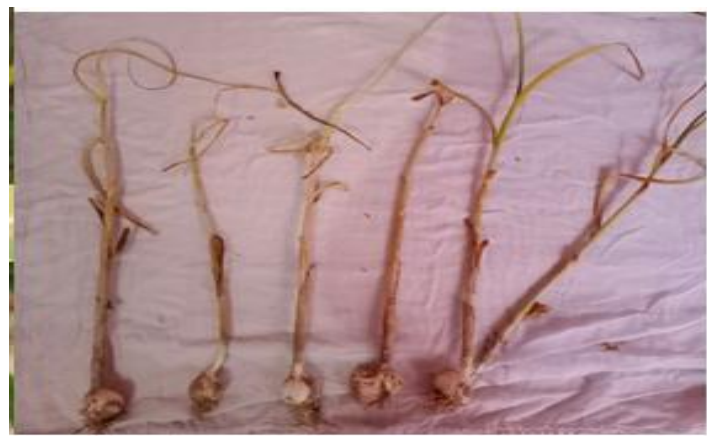

Effect of bioresources on yield reveals that yield significantly increased from untreated control $\mathrm{T}_{0}(43.4 \mathrm{q} / \mathrm{ha})$. Maximum yield was observed in treatment $\mathrm{T}_{6} \quad(132.58 \mathrm{q} / \mathrm{ha})$ followed by $\mathrm{T}_{3}(120.21 \mathrm{q} / \mathrm{ha}), \mathrm{T}_{2}(112.05 \mathrm{q} / \mathrm{ha})$, $\mathrm{T}_{4}(100.94 \mathrm{q} / \mathrm{ha}), \quad \mathrm{T}_{5}(85.72 \mathrm{q} / \mathrm{ha})$ and $\mathrm{T}_{1}$ $(72.91 \mathrm{q} / \mathrm{ha})$. However, among the treatments all the treatments were found significant over control.

Effect of bioresources on number of cloves, bulb weight, bulb diameter reveals that among 
treatments T6(Microalgae $+\mathrm{VC}+\mathrm{SMC}$ ) exhibited significantly highest average number of cloves (21), bulb weight $(30.0 \mathrm{~g})$, bulb diameter $(5.61 \mathrm{~cm})$ when compared to control.

Botanical extracts reduced the radial mycelial growth of Fusarium oxysporum f. sp cepae. Among five botanicals Ageratum conyzoides @ 15\% reduced the radial mycelial growth $(89.52 \%)$. Similar findings were reported by Priyanka et al., (2014) stated that Ageratum conyzoides exhibited maximum inhibition (95.57\%) against the Fusarium oxysporum when compared to other botanicals.

The inhibitory effects of Ageratum conyzoides on several fungi was also reported by Javed and Bashir, 2012.

Application of bioresources in field condition reduced the disease incidence of Fusarium oxysporum f.sp cepae and disease intensity of Alternaria porri of garlic, and increased the yield of garlic. Noble, 2005; Bonanomi et al., (2007); Abbasi et al.,(2001) reported that Suppression of soil-borne plant diseases with composts.

The present experimental study indicates that $_{6}$ (Microalgae+VC+SMC) shows minimum disease incidence $(18 \%)$ of Fusarium oxysporum f. sp cepae and minimum disease intensity $(20.47 \%)$ of Alternaria porri with highest yield $(132.58 \mathrm{q} / \mathrm{ha})$, plant height $(74.66 \mathrm{~cm})$. and Ageratum conyzoides exhibited maximum inhibition (95.57\%) against the Fusarium oxysporum f.sp cepae in in-vitro.

It has been concluded from present research that certain bioresources and botanical extracts are a source of cost effective and nonhazardous treatments to control diseases and to enhance yield, also they don't have human and environment, health hazard or implications.

\section{References}

Abbasi, P. A., Al-Dahmani, J., Sahin, F., Hoitink, H. A. J. and Miller, S. A. (2001). Effect of compost amendments on disease severity and yield of tomato in conventional and organic production systems. The American Phyto pathological Society. 86.

Ahlawat, O. P. and Sagar, M. P. (2007). Management of spent mushroom substrate. Technical Bulletin, National Research Centre for Mushroom (ICAR).

Booth, C. (1975). The status of Fusarium taxonomy. Annual Review of Phytopathology. 3613 (13):83-93.

Bonanomi, G., Antignani, V. Pane, C. and Scala, F. (2007). Suppression of soilborne fungal diseases with organic amendments. Journal of Plant Pathology. 89 (3): 311324.

Domenico, R., Elisa, B., Katia, P., Domenico C., Elio, C. andAldo, T. (2019). Microalgal bio stimulants and biofertilizers in crop productions. Agronomy. 9:192.

Ellis, M. B. (1971). Dematiaceous hyphomycetes, published by commonwealth mycological institute Kew, Surrey, England,485-487.

Ghangaonkar, N. M. (2013). Incidence of mycoflora on garlic (Allium Sativum L.) bulbs. International Research Journal of Biological Sciences. 2(7):64-66.

Ghante, P. H, Kanase, K. M, Markad, H. N, Suryawanshi, A. P and Chavan, P. G (2019). In-vitro efficacy of phyto-extracts against Fusarium oxysporum $f$. sp. udum causing wilt disease of pigeon pea.Journal of Pharmacognosy and Phytochemistry. $8(2): 19-21$.

Gupta, R.C. Pandey, N.K.and Gupta, R.P. (2014). Management of purple blotch (Alternaria porri) diseaseof garlic (Allium sativum L.). Journal of Spices and Aromatic Crops. 23(1): 115-118.

Janardan, L. (2017). Vermicompost and its role in plant growth promotion. International Journal of Research. 04:849.

Javed, S. and Bashir, U. (2012). Antifungal activity of different extracts of Ageratum conyzoides for the management of Fusarium solani. African Journal of Biotechnology. 11(49):11022-11029. 
Lazcanoa, C. and Dominguez, J. (2011). The use of vermicompost in sustainable agriculture: impact on plant growth and soil fertility, Nova Science Publishers, Hauppauge, 1-23.

McKinney, H. H. (1923). A new system of grading of plant diseases. Journal of Agricultural Research. 26:195-218.

Muhammad, M. T., Abdullahi, A., Jafaru, S. and Lema, S. Y. (2016). A survey of mycoflora of garlic cloves (Allium sativum L.) in Sokoto metropolis, Nigeria. Annals of Biological Sciences. 4(1):1-5.

Nene, Y. L., and Thapliyal, P. N., (1993). "Fungicides in plant disease control (3rd ed.)". Oxford and IBH Publishing Company Private limited.

Noble, R. (2005). Suppression of soil-borne plant diseases with composts. Biocontrol Science and Technology. 15(1):3-20.

Noble, R. (2011). Risks and benefits of soil amendment with composts in relation to plant pathogens. Journal of the Australasian Plant Pathology Society. 40(2):157-167.

Patil,M. G., Rathod, P. K. and Patil, V. D.(2018). Compost:A tool form an aging soilborne plant pathogens. International Journal of Current Microbiology and Applied Sciences. 6: 272-280.

Prajapati, M., Sobita, S. and Kunwar, Z. K. (2018). Efficacy of organic amendments against the purple blotch of garlic caused by Alternaria porri (Ellis) Cif. Journal of Pharmacognosy and Phytochemistry. 8(1):08-10.

Pramodkumar,T. and Palakshappa,M. G.(2009). Effect of organic amendments on antagonists and pathogen causing purple blotch of onion. Karnataka Journal of Agriculture Sciences. 22(1):229- 230.

Priyanka, M., Pooja, S. and Tripathi, N. N (2014). Evaluation of plant extracts against
Fusarium oxysporum f. sp. lycopersici, wilt pathogen of tomato. International Journal of Food, Agriculture and Veterinary Sciences. 4(2):163-167.

Ramniwas, Y., Bairwa, H. L. and Gurjar. (2017). Response of garlic (Allium sativum L.)to organic manures and fertilizers. International journal of Current Microbiology Applied Sciences. 6(10):4860-4867.

Raouf, N., Al-Homaidan, A. A. and Ibraheem, I. B. M (2012). Agricultural importance algae. African Journal of Biotechnology. 11(54): 11648-11658.

Shalaby,T. A.,andHassan,El-Ramady.(2014). Effect of foliar application of biostimulants on growth, yield, components, and storability of garlic (Allium sativum L.). AJCS. 8(2): 271-275.

Takakuwa, Nobuyuki, I., Fujio, K. and Izumi, S. (1977). Host range of Fusarium oxysporum f. sp.cepae, causal fungus of fusarium basal rot of onion. Ann. Phytopath. Soc. Japan. 43:479-481.

Shikha, S. and Ratnoo, R. S. (2018). Study on effect of host age and host rang of Alternaria porri. Journal of Pharmacognosy and Phytochemistry. 8(1): 1295-1297.

Yusidah,I., Istifadah, N. (2018). The abilities of spent mushroom substrate to suppress basal rot disease (Fusarium oxysporum $\mathrm{f}$. spcepae) in shallot. International Journal of Biosciences. 13(1):440-448.

Zeeshan, M.A, Imran, K., Bismillah S., Ahmad N., Nangial K., Waseem U., Muhammad A., Syed R.A., Khwaja J., Mazhar I. (2016). Study on the management of Ralstonia solanacearum (Smith) with spent mushroom compost. Journal of Entomology and Zoology Studies. 4(3):114-121.

\section{How to cite this article:}

Vineeth Masireddy and Sobita Simon. 2021. Effect of Bioresources on Fusarium Basal Rot and Purple Blotch Diseases of Garlic (Allium sativum). Int.J.Curr.Microbiol.App.Sci. 10(05): 605614. doi: https://doi.org/10.20546/ijcmas.2021.1005.068 